\title{
Helicobacter pylori heat-shock protein 60 induces interleukin-8 via a Toll-like receptor (TLR)2 and mitogen-activated protein (MAP) kinase pathway in human monocytes

\author{
Ying Zhao, Kenji Yokota, Kiyoshi Ayada, Yumiko Yamamoto, \\ Tomayuki Okada, Lianhua Shen and Keiji Oguma
} \\ Correspondence \\ Kenji Yokota \\ yokochan@md.okayama-u.ac.jp \\ Received 10 August 2006 \\ Accepted 3 October 2006

\author{
Department of Bacteriology, Graduate School of Medicine, Dentistry and Pharmaceutical \\ Sciences, Graduate School of Health Science, Okayama University, 2-5-1 Shikata-cho,
} Okayama 700-8558, Japan
}

\section{INTRODUCTION}

Helicobacter pylori is an important human pathogen that causes gastritis and is strongly associated with peptic ulcer, gastric adenocarcinoma, and mucosa-associated lymphoid tissue lymphoma. H. pylori has been found in people worldwide, with over half of the world's population infected (Mann \& Westblom, 1999). One remarkable feature of the infection is that it persists throughout the life of the host in the face of a significant inflammatory response. Only a few carriers suffer peptic ulceration and gastric cancer, because the host immune response may play important roles in clinical outcome; e.g. inflammatory processes might take place within the gastric mucosa via activation of monocytes/macrophages as antigen-presenting

Abbreviations: ERK, extracellular signal-regulated kinase; GST, glutathione S-transferase; H. pylori-HSP60, Helicobacter pylori heat-shock protein 60; HSP, heat-shock protein; IL, interleukin; JNK, c-Jun Nterminal kinase; LBP, LPS-binding protein; MAPK, mitogen-activated protein kinase; NF- $\kappa \mathrm{B}$, nuclear factor- $\kappa \mathrm{B}$; $\mathrm{rHpHSP60}$, recombinant $H$. pylori HSP60; siRNA, small interfering RNA; TLR, Toll-like receptor. cells. Macrophage-derived cytokine production is strongly upregulated during $H$. pylori infection in non-human primates (Harris et al., 2000). These innate and adaptive responses are principally characterized by increased infiltration of lymphocytes and macrophages into infected gastric tissues (Sarsfield et al., 1996; Suzuki et al., 2002).

A recent study has shown that the $60 \mathrm{kDa}$ heat-shock protein (HSP) HSP60, a potent immune antigen of H. pylori, induces interleukin (IL)-6 secretion from mouse monocytes (Gobert et al., 2004). Not only monocytes/macrophages but also neutrophils have an important role during chronic infection in the early and active stages of inflammation. Neutrophils are directly activated by neutrophil-activating protein (NAP) from the bacteria (Brisslert et al., 2005; Evans et al., 1995). In addition, IL-8 is associated with this phenomenon as a powerful neutrophil chemoattractant. IL8 is secreted from epithelial cells by bacterial virulence factors such as the cag pathogenicity island (cagPAI) and OipA (Crabtree et al., 1995; Yamaoka et al., 2000). We have previously reported that $H$. pylori-HSP60 may induce IL-8 
secretion from gastric epithelial cells (Takenaka et al., 2004). In addition, monocytes also secrete IL-8, and this reaction is inhibited by anti-H. pylori-HSP60 mAbs (Lin et al., 2005). These results indicate that the interaction between monocytes and HSP60 may play an important role in gastric inflammation in $H$. pylori infection.

The mitogen-activated protein kinases (MAPKs) are an important group of serine and threonine signalling kinases that transduce a variety of extracellular stimuli through a cascade of protein phosphorylations, leading to transcription factor activation (Kyriakis \& Avruch, 2001). $\mathrm{Cag}^{+} \mathrm{H}$. pylori can induce IL-8 production via the activation of ERK, p38 and c-Jun N-terminal kinase (JNK) MAPKs in gastric epithelial cells (Keates et al., 1999). The role of MAPK in regulating nuclear factor- $\kappa \mathrm{B}(\mathrm{NF}-\kappa \mathrm{B})$ transactivation remains controversial. Aihara et al. (1997) have shown that both the NF- $\kappa \mathrm{B}$ and activating protein 1 (AP-1) DNA binding sites within the IL- 8 promoter are required for optimal transcription in response to infection of gastric epithelial cells by $H$. pylori. MAPK signalling pathways activate NF- $\kappa \mathrm{B}$ and/or AP- 1 and can result in increased IL-8 secretion from human monocytes in $H$. pylori infection (Bhattacharyya et al., 2002). Toll-like receptors (TLRs) are a key component of the host innate recognition system against bacterial components (Zhang et al., 2004). TLR2, TLR4 and TLR5 are closely associated with cytokine production and activation of signalling pathways in $H$. pylori infection (Kawahara et al., 2001; Ishihara et al., 2004; Smith et al., 2003; Takenaka et al., 2004).

Based on these findings, we inferred that the mechanism of IL-8 secretion induced by interaction between HSP60 and monocytes may be important for gastric inflammation. In this study, activation of ERK1/2, p38 and JNK of the MAPK signalling pathway was assessed when stimulated with intact $H$. pylori, heat-killed $H$. pylori or recombinant $H$. pylori HSP60 (rHpHSP60). In addition, we also investigated whether TLR2 is involved in MAPK signalling and NF- $\kappa \mathrm{B}-$ mediated activity of IL-8 secretion from rHpHSP60-infected monocytes. Thus, our goal was to describe how HSP60, as a potent $H$. pylori immune antigen, is responsible for the induction of IL-8 in human monocytes.

\section{METHODS}

Bacterial strains. H. pylori standard strain ATCC $43504 \mathrm{CagA}^{+}$, $\mathrm{VacA}^{+}$), obtained from the American Type Culture Collection (ATCC), was used. This strain is commonly used for animal experiments (Yokota et al., 1991; Iwao et al., 1999). Before each experiment, H. pylori was cultured on brain heart infusion agar supplemented with $7 \%$ sterile defibrinated horse blood at $37^{\circ} \mathrm{C}$ in a microaerophilic chamber containing $10 \% \mathrm{CO}_{2}, 5 \% \mathrm{O}_{2}$ and $85 \%$ $\mathrm{N}_{2}$. After 3 days of incubation, $H$. pylori was harvested into RPMI1640 (Gibco) without fetal bovine serum (FBS) to an $\mathrm{OD}_{600}$ of 1.0 , corresponding to approximately $1 \times 10^{8}$ c.f.u. $\mathrm{ml}^{-1}$. Heat-killed H. pylori was prepared by heating in a $60^{\circ} \mathrm{C}$ water bath for $30 \mathrm{~min}$.

Cell culture. The human monocytic cell lines NOMO1and U937 were obtained from the Japanese Collection of Research Bioresource
(Tokyo, Japan). Both were maintained in RPMI 1640 supplemented with $10 \% \mathrm{FBS}, 50 \mathrm{IU}$ penicillin $\mathrm{ml}^{-1}, 50 \mu \mathrm{g}$ streptomycin $\mathrm{ml}^{-1}$ (ICN Biomedical) and $2.5 \mu \mathrm{g}$ amphotericin $\mathrm{B} \mathrm{ml}^{-1}$ (ICN Biomedical) at $37{ }^{\circ} \mathrm{C}$ in an atmosphere of $5 \% \mathrm{CO}_{2}$ and $99 \%$ humidity. Cells were washed three times by RPMI 1640 without antibiotics before each experiment and used at a final concentration of $1 \times 10^{5}-$ $3 \times 10^{6}$ cells $\mathrm{ml}^{-1}$. Cytotoxic effect was determined by the CytoTox 96 Non-Radioactive Cytotoxicity Assay (Promega), after cells had been cultured with $H$. pylori, rHpHSP60, several inhibitors and small interfering RNA (siRNA). No mediation of cytotoxicity by these antigens or agents was detected at the concentrations and incubation times employed during this work.

rHpHSP60 preparation. $\mathrm{rHpHSP} 60$ was prepared as described by Ishii et al. (2001). In brief, the ORF of HSP60 taken from H. pylori ATCC 43504 genomic DNA was amplified and cloned into the vector pGEX-5X3 (Amersham Biosciences). The resultant plasmid was transformed into Escherichia coli DH5 $\alpha$. Cells were cultured in Luria-Bertani broth containing $2 \%$ glucose and $100 \mu \mathrm{g}$ ampicillin $\mathrm{ml}^{-1}$, harvested by centrifugation, and disrupted by sonication on ice for $5 \mathrm{~min}$ with a probe sonicator (Astron). Soluble fusion protein expressed by the HSP60 clone was purified by glutathione-Sepharose $4 \mathrm{~B}$ affinity chromatography (Amersham Biosciences) according to the manufacturer's instructions. The purity of the proteins was determined by SDS-PAGE using a $12 \%$ running gel, and a $60 \mathrm{kDa}$ protein band was revealed by Coomassie brilliant blue staining. That the $60 \mathrm{kDa}$ protein belonged to $H$. pylori was confirmed by amino acid sequence analysis. The concentration $\left(\mathrm{mg} \mathrm{ml}^{-1}\right)$ of the purified protein was determined using the Bio-Rad protein assay kit (based on the Lowry assay), with $A_{655}$ measured with a microplate reader (BioRad model 680). To exclude the effects of trace amounts of LPS in the recombinant product, a Limulus amoebocyte lysate assay kit (BioWhittaker) was used according to the manufacturer's instructions. The preparations of rHpHSP60 contained $<30$ endotoxin units (EU) (mg protein) $)^{-1}$ (Takenaka et al., 2004; Lin et al., 2005).

IL-8 secretion from cells. NOMO1 or U937 cells grown on 96well plates were stimulated with intact, heat-killed $H$. pylori, rHpHSP60, glutathione S-transferase (GST), or LPS from Salmonella enteriditis (Sigma) at $37^{\circ} \mathrm{C}$ in serum-free RPMI1640 for the specified time and at the specified concentration. For inhibition by blocking cell surface molecules, cells were pre-incubated for $30 \mathrm{~min}$ with $10 \mu \mathrm{g} \mathrm{ml}^{-1}$ anti-TLR2 antibodies (HyCult Biotechnology), $10 \mu \mathrm{g} \mathrm{ml}^{-1}$ anti-TLR4 antibodies (Sanbio), $10 \mu \mathrm{g} \mathrm{ml}^{-1}$ anti-IL-1 antibodies (Rockland) and $50 \mu \mathrm{g} \mathrm{ml}^{-1}$ anti-CD14 antibodies (R\&D Systems). For inhibition of MAPK signalling pathways, PD98059 (Promega) and U0126 (Cell Signalling Technology) for ERK1/2 signalling, and SB203580 (Promega) for p38 signalling, were added at the indicated concentrations for $30 \mathrm{~min}$ at $37^{\circ} \mathrm{C}$ before treatment with $\mathrm{rHpHSP60}$. Supernatants and cells were separated by centrifugation at $300 \mathrm{~g}$ and stored at $-80^{\circ} \mathrm{C}$ until assayed. Supernatants were assayed for IL- 8 production, and IL- 8 was measured by ELISA (IL-8 ELISA development kit, Techne).

Detection of MAPK phosphorylation. NOMO1 cells were stimulated with bacterial cells or rHpHSP60, and the cells were harvested by centrifugation. After washing in PBS/phosphatase inhibitor buffer [PIB; $125 \mathrm{mM} \mathrm{NaF}, 250 \mathrm{mM} \beta$-glycerophosphate, $250 \mathrm{mM}$ p-nitrophenylphosphate (PNPP) and $25 \mathrm{mM} \mathrm{NaVO}_{3}$ ], cells were lysed in $50 \mu$ lysis buffer $(50 \mathrm{mM}$ Tris- $\mathrm{HCl}, \mathrm{pH} 7.4,150 \mathrm{mM} \mathrm{NaCl}, 1 \mathrm{mM}$ EDTA, $1 \%$ Nonidet P-40, $0.25 \%$ sodium deoxycholate, $1 \mathrm{mM}$ PMSF, $1 \mathrm{mM} \mathrm{NaVO}, 1 \mathrm{mM} \mathrm{NaF}, 1 \mu \mathrm{g}$ leupeptin $\mathrm{ml}^{-1}, 1 \mu \mathrm{g}$ aproti$\operatorname{nin} \mathrm{ml}^{-1}$ and $1 \mu \mathrm{g}$ pepstatin $\mathrm{A} \mathrm{m}{ }^{-1}$ ). After incubation on ice for $20 \mathrm{~min}$, cells were sonicated, and whole-cell lysates were collected by centrifugation at $10000 \mathrm{~g}$ for $5 \mathrm{~min}$. Cell lysates were mixed with equal volumes of $2 \times$ SDS sample buffer and boiled for $5 \mathrm{~min}$. Cell lysates were subjected to SDS-PAGE using $14 \%$ running gels. The proteins were then transferred to PVDF membranes (Millipore). The 
membranes were washed with Tris-buffered saline (TBS) and blocked with $5 \%(\mathrm{w} / \mathrm{v})$ non-fat milk in TBS/Tween $20(1 \%$, v/v) (TBST) for $1 \mathrm{~h}$ at room temperature. After three washes of $5 \mathrm{~min}$ each with TBST, the membranes were incubated with antibodies to ERK, phospho-ERK, p38 or phospho-p38 MAPK (Cell Signalling Technology) in TBST with $5 \%(\mathrm{w} / \mathrm{v})$ BSA overnight at $4{ }^{\circ} \mathrm{C}$. Following three washes with TBST, the blots were incubated with an anti-rabbit IgG HRP-linked antibody (Wako) for $1 \mathrm{~h}$ at room temperature. Bands were visualized by ECL Western Blotting detection reagents (Amersham Pharmacia) and exposure to an LAS-1000 mini Bio-Imaging Analyser System (Fujifilm). The phospho-ERK or phospho-p38 intensities of the bands were analysed with Image Gauge version 4.0 software (Fujifilm) and normalized against ERK or p38 in the corresponding samples.

Nuclear extract and NF- $\boldsymbol{\kappa}$ B transcription factor assay. After stimulation with $\mathrm{rHpHSP60}$, cells were washed in ice-cold PBS/PIB. The cells were suspended in $1 \mathrm{ml}$ ice-cold hypotonic buffer (HB; $20 \mathrm{mM}$ HEPES, pH 7.5, $5 \mathrm{mM} \mathrm{NaF}, 10 \mu \mathrm{M} \mathrm{Na}{ }_{2} \mathrm{MoO}_{4}$ and $0.1 \mathrm{mM}$ EDTA) for incubation on ice for $15 \mathrm{~min}$. The cells had $50 \mu \mathrm{l} 10 \%$ Nonidet P-40 ( $0.5 \%$ final concentration) added, and the homogenate was centrifuged for $30 \mathrm{~s}$ at $4{ }^{\circ} \mathrm{C}$. The nuclear pellets were resuspended in $50 \mu \mathrm{l}$ complete lysis buffer, and the tube was rocked gently on ice for $30 \mathrm{~min}$. After centrifugation for $5 \mathrm{~min}$ at $14000 \mathrm{~g}$ at $4^{\circ} \mathrm{C}$, the supernatants (nuclear cell extracts) were saved at $-80^{\circ} \mathrm{C}$ until use. The protein concentration was determined with a Beckman DU-7000 (Lab X). NF- $\kappa$ B activation was detected and quantified by Trans AM $\mathrm{NF}-\kappa \mathrm{B}$ (Activemotif). Briefly, nuclear extracts were prepared and incubated for $1 \mathrm{~h}$ on a 96-well plate with immobilized oligonucleotide containing the NF- $\kappa \mathrm{B}$ consensus site ( $5^{\prime}$-GGGACTTTCC- $3^{\prime}$ ). After incubation with an antibody to p65 (RelA), a subunit of the activated NF- $\kappa$ B dimer, a horseradish peroxidase-conjugated secondary antibody was added, followed by developing solution including TransAM NF- $\kappa$ B. The absorbance was read at $450 \mathrm{~nm}$ with a reference wavelength of $655 \mathrm{~nm}$ on a spectrophotometer.

Real-time RT-PCR assay. NOMO1 cells were pretreated for $30 \mathrm{~min}$ with anti-TLR2 antibodies $\left(10 \mu \mathrm{g} \mathrm{ml}^{-1}\right)$ and inhibitors of MAPK signalling, before treatment with $\mathrm{rHpHSP60.} \mathrm{Total} \mathrm{RNA} \mathrm{was}$ extracted from NOMO1 cells $\left(3 \times 10^{6}\right.$ cells) by an RNeasy Mini kit (Qiagen). Briefly, the cells were resuspended in $350 \mu$ RLT buffer, removed to a QIAshredder column, and centrifuged at $12000 \mathrm{~g}$ for $2 \mathrm{~min}$. An equal volume of $70 \%$ ethanol was added to the homogenized lysates and mixed by pipetting, and up to $700 \mu$ of the sample was applied to an RNeasy mini-column. After centrifugation for $15 \mathrm{~s}$ at $8000 \mathrm{~g}$, the flow-through was discarded. A total of $700 \mu \mathrm{l}$ RW1 buffer was added for $15 \mathrm{~s}$ at $8000 \mathrm{~g}$, and again the flowthrough was discarded. Following two washes with $500 \mu \mathrm{l}$ RPE buffer and centrifugation for $2 \mathrm{~min}$ at $8000 \mathrm{~g}$, the flow-through was discarded. The RNase column was then transferred to a fresh $1.5 \mathrm{ml}$ collection tube and $30 \mu \mathrm{l}$ RNase-free water was pipetted onto the membrane, followed by centrifugation for $1 \mathrm{~min}$ at $8000 \mathrm{~g}$. The concentration and purity of RNA were determined by measuring the $A_{260}$ and the $A_{260} / A_{280}$ ratio with a Beckman DU-7000. The RNA was stored at $-80^{\circ} \mathrm{C}$ until use. For cDNA synthesis, reverse-transcription was performed by ReverTra Dash (Toyobo). Total cellular RNA $(1 \mu \mathrm{g}$ per $5 \mu \mathrm{l})$ was reverse-transcribed in $4 \mu \mathrm{l} 5 \times$ RT buffer, $2 \mu \mathrm{l}$ dNTP mixture, $1 \mu \mathrm{l}$ RNase inhibitor, $1 \mu \mathrm{l}$ Oligo (dT) 20 primer, and $1 \mu \mathrm{l}$ ReverTra Ace at $30^{\circ} \mathrm{C}$ for $10 \mathrm{~min}, 42^{\circ} \mathrm{C}$ for $20 \mathrm{~min}, 99^{\circ} \mathrm{C}$ for $5 \mathrm{~min}$, and $4^{\circ} \mathrm{C}$ for $5 \mathrm{~min}$.

Real-time PCR was performed in a LightCycler Quick System 350S (Roche Diagnostics). The cDNA ( $1 \mu \mathrm{l})$ sample was amplified in a $20 \mu \mathrm{l}$ reaction mixture containing $2 \mu 110 \times$ FastStart DNA Master SYBR Green (Roche Diagnostics), $2 \mu \mathrm{l}$ IL-8 primer mix or $2 \mu \mathrm{l}$ glucose-6phosphate dehydrogenase (G6PDH) primer mix (Roche Diagnostics), and $15 \mu \mathrm{l} \mathrm{H}_{2} \mathrm{O}$. The PCR reaction was then initiated at $95^{\circ} \mathrm{C}$ for
10 min to activate the modified Taq polymerase, followed by 45 cycles of $95^{\circ} \mathrm{C}$ for $10 \mathrm{~s}, 68^{\circ} \mathrm{C}$ for $10 \mathrm{~s}$, and $72^{\circ} \mathrm{C}$ for $16 \mathrm{~s}$, and one cycle of $55^{\circ} \mathrm{C}$ for $10 \mathrm{~s}$ and $40^{\circ} \mathrm{C}$ for $30 \mathrm{~s}$. The specificity of the PCR product was checked by the melting curve, which showed that the melting temperature was in a very narrow range from 84 to $85^{\circ} \mathrm{C}$ for IL-8, and 90 to $91{ }^{\circ} \mathrm{C}$ for G6PDH. The data were analysed by LightCycle software version 3.5 (Roche Diagnostics), and the ratio of IL-8 to G6PDH was calculated.

Transfection of siRNA. Sequences of TLR2 siRNA were predesigned by Ambion. The siRNA sequences were as follows: 5' GGAUCACCUACAUUAGCAAtt- ${ }^{\prime}$ (sense) and 5' ${ }^{\prime}$-UUGCUAAUGUAGGUGAUCCtg- $3^{\prime}$ (antisense). Silencer negative-control siRNA was purchased from Ambion. NOMO1 cells were transfected with $30 \mu \mathrm{M}$ siRNA per $1 \times 10^{5}$ cells and $6.25 \mu \mathrm{l}$ siPORT NeoFX transfection agent (Ambion). In brief, cells were suspended to $1 \times 10^{5} \mathrm{ml}^{-1}$ in OPTI-MEMI reduced serum medium (Gibco Invitrogen) and kept at $37^{\circ} \mathrm{C}$ while preparing the transfection complexes. A total of $2.5 \mu \mathrm{l} \mathrm{NeoFX} \mathrm{transfection} \mathrm{agent} \mathrm{was} \mathrm{diluted} \mathrm{in}$ $50 \mu \mathrm{l}$ OPTI-MEMI medium and incubated for $10 \mathrm{~min}$ at room temperature. Then, 15 pmol siRNA was diluted in $50 \mu$ l OPTI-MEMI medium, and the siRNA and transfection agent were mixed and incubated at room temperature for $10 \mathrm{~min}$. The RNA-transfection agent complexes were dispensed into a 24 -well plate, followed by transfer of $400 \mu \mathrm{l}$ of cells to the culture plate, gentle mixing, and incubation at $37^{\circ} \mathrm{C}$. After $5 \mathrm{~h}, 100 \mu \mathrm{l} \mathrm{FBS}$ was added to the cells. At $72 \mathrm{~h}$ post-transfection, $50 \mu \mathrm{g} \mathrm{rHpHSP} 60 \mathrm{ml}^{-1}$ was added, and IL-8 was analysed using ELISA after an additional $3 \mathrm{~h}$. Knockdown of TLR2 after transfection was confirmed by flow cytometry from $72 \mathrm{~h}$ post-transfection.

Flow cytometry analysis. TLR2 expression on the surface of NOMO1 cells was determined by flow cytometry. Cells were stained with anti-TLR2 antibodies or mouse IgG1 $\kappa$ (Sigma), which served as a control, for $1 \mathrm{~h}$ and labelled with bovine anti-mouse IgG-phycoerythrin (PE) (Santa Cruz) for $30 \mathrm{~min}$. All staining procedures were completed at $4{ }^{\circ} \mathrm{C}$ in PBS containing $0.02 \%$ azide and $0.2 \%$ BSA. Samples were then fixed in $2 \%$ paraformaldehyde/0.1 M phosphate buffer ( $\mathrm{pH}$ 7.3) for $20 \mathrm{~min}$ and analysed in a Becton Dickinson FACScalibur immunocytometry system (BD Biosciences).

Statistical analysis. Results were expressed as mean \pm SD. Data were compared using Student's $t$ test, and differences were considered significant at $P$ values of less than 0.05 .

\section{RESULTS}

\section{Intact $\boldsymbol{H}$. pylori, heat-killed $\boldsymbol{H}$. pylori and rHpHSP60 induced MAPK activation in human monocytes}

The MAPK pathway has been implicated in the induction of cytokines in human monocytes via bacterial stimulation. We thus assessed the role of MAPK in the secretion of IL- 8 by $H$. pylori-HSP60 stimulation. The time-course of IL- 8 production from monocytes was assayed, and maximum production by intact or heat-killed $H$. pylori-stimulated NOMO1 cells appeared at $6 \mathrm{~h}$; rHpHSP60 induction of IL-8 secretion reached its maximum at $3 \mathrm{~h}$ (Fig. 1a). In U937 cells, treatment with intact $H$. pylori, heat-killed $H$. pylori or rHpHSP60 for $24 \mathrm{~h}$ resulted in peak IL-8 production (Fig. 1b). The time-dependent MAPK phosphorylation was measured to assess the activation of these kinases upon treatment with intact H. pylori, heat-killed H. pylori and 

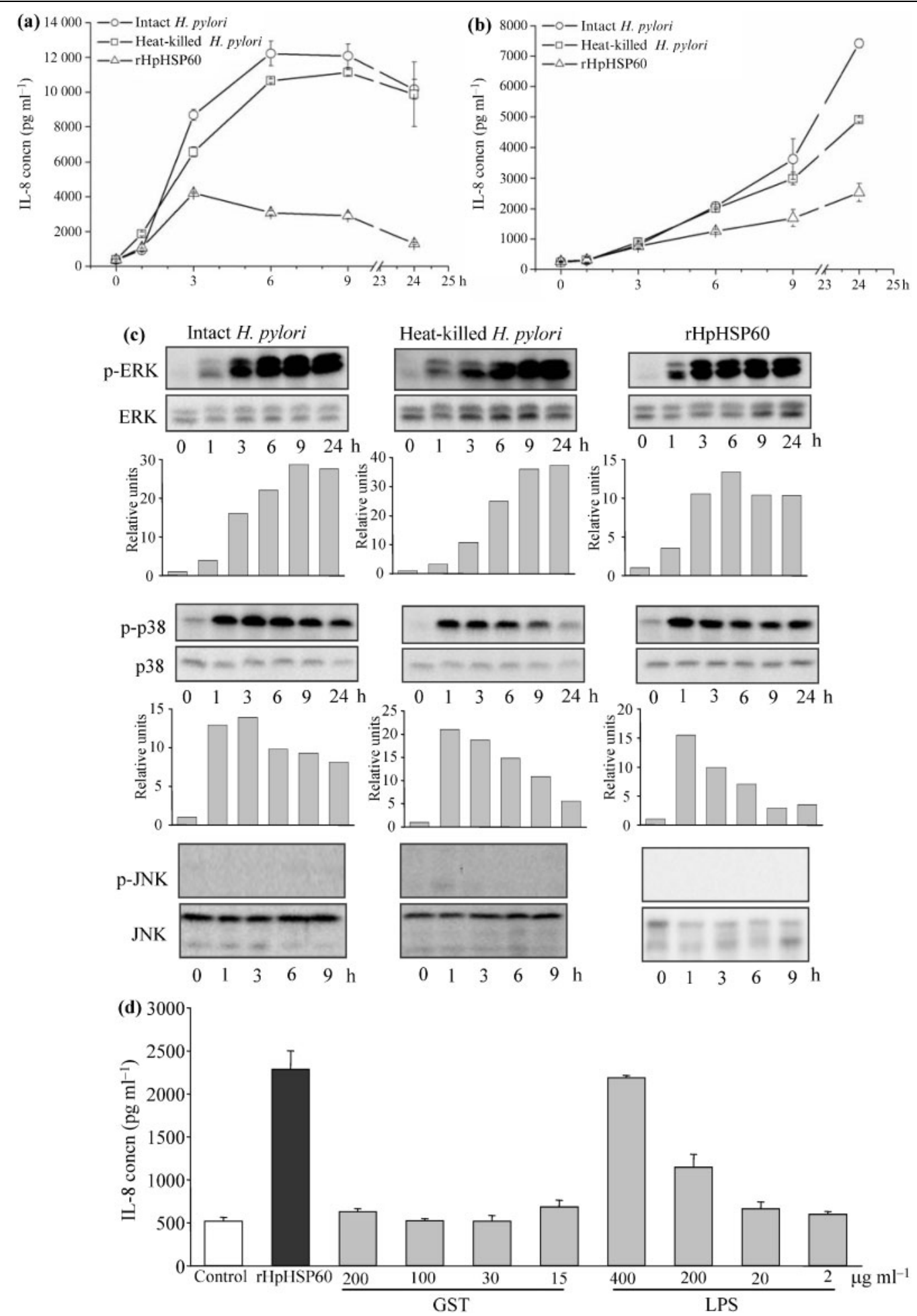

Fig. 1. Intact $H$. pylori, heat-killed $H$. pylori, and $\mathrm{rHpHSP} 60$ induce IL-8 production and stimulate ERK and p38 MAPK activation in a time-dependent manner in monocytes. (a) NOMO1 cells $\left(2 \times 10^{6} \mathrm{ml}^{-1}\right)$ or (b) U937 cells $\left(2 \times 10^{6} \mathrm{ml}^{-1}\right) \mathrm{were}^{\mathrm{w}}$

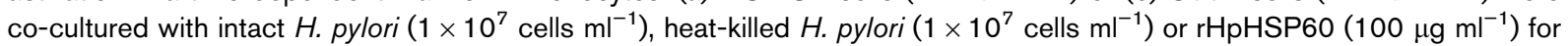
1-24 $\mathrm{h}$. The cell supernatants were measured for IL-8 release. Data are expressed as mean \pm SD $(n=3)$. (c) NOMO1 cell lysates were analysed by Western blotting using antibodies to phospho-ERK ( $p-E R K$ ), phospho-p38 (p-p38) or phospho-JNK $(p-J N K)$ at the indicated time points. Antibodies to unphosphorylated ERK, p38 or JNK served as protein loading controls. Image Gauge software was used to calculate relative units to indicate the fold difference between stimulated and nonstimulated cells after normalizing against ERK or p38. (d) NOMO1 cells were stimulated with $\mathrm{rHpHSP} \mathrm{NO}\left(100 \mu \mathrm{g} \mathrm{m} \mathrm{l}^{-1}\right), \mathrm{GST}$ and LPS for $16 \mathrm{~h}$ at the indicated concentrations. The cell supernatants were measured for IL-8 release. Data are expressed as mean $\pm \mathrm{SD}(n=3)$. 

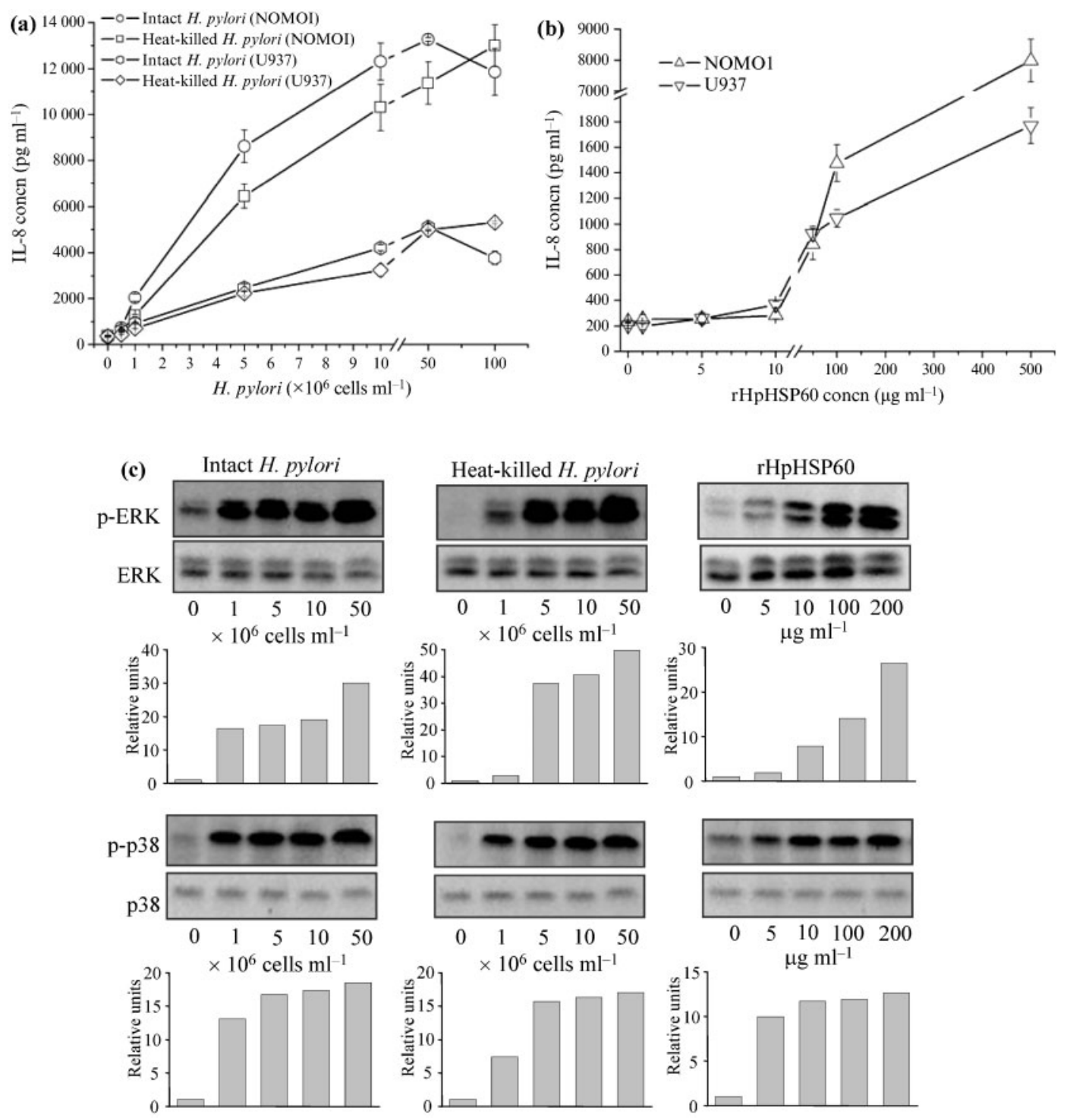

Fig. 2. Intact $H$. pylori, heat-killed $H$. pylori and rHpHSP60 induce IL-8 production and stimulate ERK and p38 MAPK activation in a dose-dependent manner in monocytes. (a) Cells $\left(2 \times 10^{6} \mathrm{ml}^{-1}\right)$ were treated with intact or heat-killed $H$. pylori for $9 \mathrm{~h}$ with the indicated numbers of bacteria. (b) Cells $\left(2 \times 10^{6} \mathrm{ml}^{-1}\right)$ were treated with $\mathrm{rHpHSP} 60$ for $9 \mathrm{~h}$ with the indicated concentrations. IL-8 release was measured from the cell supernatants. Data are expressed as mean \pm SD $(n=3)$. (c) NOMO1 cell lysates were analysed by Western blotting using antibodies to either phospho-ERK (p-ERK) or phospho-p38 (p-p38) at the indicated concentrations. Antibodies to unphosphorylated ERK or p38 served as protein loading controls. Image Gauge software was used to calculate relative units to indicate the fold difference between stimulated and non-stimulated cells after normalizing against ERK or p38.

rHpHSP60 in NOMO1 cells (Fig. 1c). ERK activation was observed at $3 \mathrm{~h}$, and peaked at 9,24 and $6 \mathrm{~h}$ by stimulation with intact $H$. pylori, heat-killed $H$. pylori and rHpHSP60, respectively. p38 activation by intact $H$. pylori stimulation was observed at $1 \mathrm{~h}$ and peaked at $3 \mathrm{~h}$, while activation by heat-killed $H$. pylori and rHpHSP60 peaked at $1 \mathrm{~h}$. However, activation persisted under all treatments for longer periods of up to $24 \mathrm{~h}$. JNK activation was not observed as a result of any stimulation (Fig. 1c). To determine the effects of GST and LPS on IL-8 secretion from NOMO1 cells, GST or LPS at different concentrations was used to treat NOMO1 cells. No effect of GST stimulation was detected, but it was found that LPS induced IL-8 secretion in a dose-dependent manner (Fig. 1d).

IL-8 production and MAPK activation were also found to be dose dependent. IL-8 production from NOMO1 was higher than that from U937 cells for a given number of bacteria. The peak of IL-8 secretion from NOMO1 and U937 appeared at stimulation with $5 \times 10^{7}$ cells ml $^{-1}$ intact 
(a)
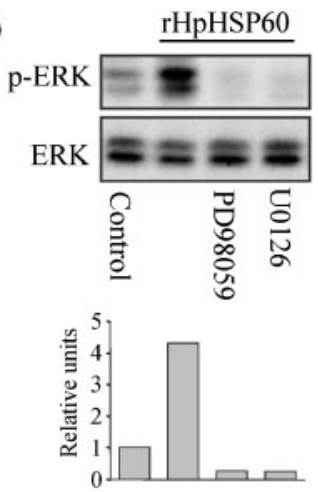
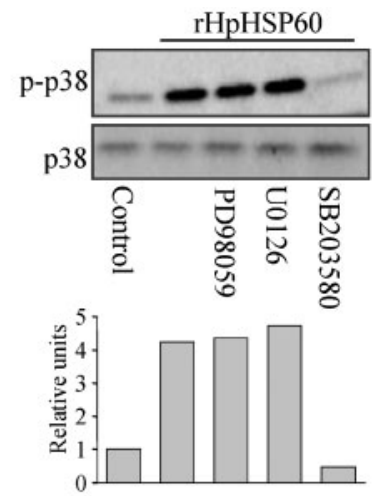

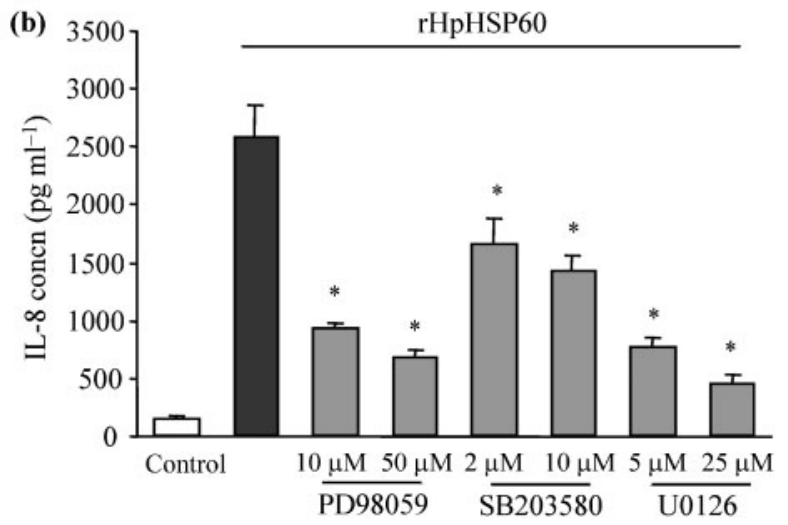

Fig. 3. PD98059, U0126 and SB203580 inhibit ERK and p38 MAPK activation and IL-8 release in $\mathrm{rHpHSP60-treated} \mathrm{mono-}$ cytes. (a) NOMO1 cells $\left(2 \times 10^{6} \mathrm{ml}^{-1}\right)$ were pretreated for $30 \mathrm{~min}$ with PD98059 $(30 \mu \mathrm{M})$, U0126 (10 $\mu \mathrm{M})$ and SB203580 $(5 \mu \mathrm{M})$ before incubation with $\mathrm{rHpHSP60}$ $\left(100 \mu \mathrm{g} \mathrm{ml}^{-1}\right)$ for $3 \mathrm{~h}$. The cell lysates were analysed by Western blotting using antibodies to either phospho-ERK ( $p$ ERK) or phospho-p38 (p-p38). Antibodies to unphosphorylated ERK or p38 served as protein loading controls. Image Gauge software was used to calculate relative units to indicate the fold difference between $\mathrm{rHpHSP60-stimulated} \mathrm{and} \mathrm{non-stimu-}$ lated cells after normalizing against ERK or p38. (b) NOMO1 cells $\left(2 \times 10^{6} \mathrm{ml}^{-1}\right)$ were pretreated for $30 \mathrm{~min}$ with PD98059, SB203580 and U0126 at the indicated concentrations before incubation with $\mathrm{rHpHSP} 60\left(100 \mu \mathrm{g} \mathrm{ml}^{-1}\right)$ for $3 \mathrm{~h}$. The cell supernatants were measured for IL-8 release. Data are expressed as mean \pm SD $(n=3)$. ${ }^{*} P<0.05$ compared with rHpHSP60 stimulation without inhibitor.

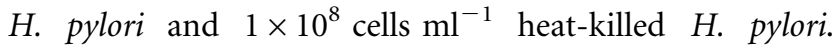
Moreover, the highest concentration of intact $H$. pylori seemed to influence monocytes; IL-8 secretion declined with stimulation by $1 \times 10^{8}$ cells $\mathrm{ml}^{-1}$ intact $H$. pylori (Fig. $2 \mathrm{a}$ ). rHpHSP60 induced IL-8 secretion in a dose-dependent manner from NOMO1 and U937 cells (Fig. 2b). ERK activation increased to an obvious extent with stimulation by $1 \times 10^{6}$ cells $\mathrm{ml}^{-1}$ intact $H$. pylori, and activation induced by heat-killed $H$. pylori increased at $5 \times 10^{6}$ cells $^{-1}$. ERK activation in NOMO1 cells became greater with stimulation

by $10 \mu \mathrm{g} \mathrm{rHpHSP} 60 \mathrm{ml}^{-1}$. p38 activation increased to an obvious extent with stimulation by $1 \times 10^{6} \mathrm{cells} \mathrm{m}^{-1}$ of both intact and heat-killed $H$. pylori, and p38 activation induced by rHpHSP60 increased at $5 \mu \mathrm{g} \mathrm{ml}^{-1}$ (Fig. 2c). These results indicate that intact $H$. pylori, heat-killed $H$. pylori and rHpHSP60 induced both IL-8 secretion and ERK and p38 MAPK activation in human monocytes. NOMO1 cells were used in the subsequent experiment because IL-8 production and MAPK activation in NOMO1 cells were comparatively potent.

\section{Inhibition of rHpHSP60-induced IL-8 production from monocytes}

To identify whether MAPK signalling is responsible for IL-8 secretion, the effects of PD98059, U0126 and SB203580 on ERK and $\mathrm{p} 38$ activation were investigated with $\mathrm{rHpHSP} 60$ stimulation in NOMO1 cells. ERK1/2-specific inhibitors (PD98059 and U0126) or a p38-specific inhibitor (SB203580) were applied before rHpHSP60 stimulation. PD98059 and U0126 inhibited ERK phosphorylation (Fig. 3a, left), and SB203580 inhibited p38 phosphorylation (Fig. 3a, right). IL-8 production stimulated by $\mathrm{rHpHSP60}$ was also significantly decreased by these specific inhibitors of ERK $1 / 2$ and p38 in a dose-dependent manner in NOMO1 cells (Fig. 3b). The results indicated the involvement of ERK and p38 activation in rHpHSP60-induced IL-8 secretion.

Next, we investigated whether cell surface molecules were associated with IL-8 secretion from monocytes. Anti-TLR2, -TLR4, -CD14 and -IL-1 receptor antibodies were employed to pre-treat NOMO1 cells before rHpHSP60 stimulation. Blocking of TLR2 significantly reduced IL-8 secretion from NOMO1 cells; however, treatment with anti-TLR4, -CD14 and -IL1 receptor antibodies did not affect IL-8 secretion (Fig. 4a). Blocking of TLR2 also inhibited ERK and p38 MAPK activation (Fig. $4 \mathrm{~b}$ ). In addition, to demonstrate that TLR2 participates in the response to $\mathrm{rHpHSP60-mediated}$ IL-8 secretion, we used siRNA targeting TLR2 in human monocytes. The knockdown effect was quantified by flow cytometry. The siRNA treatment decreased TLR2 expression by $50 \%$ in the cells compared with the results for negativecontrol siRNA (Fig. 4c). Cells with TLR2 knockdown $(50 \%)$ exhibited a $23 \%$ decrease in IL-8 production in response to the TLR2 agonists in $\mathrm{rHpHSP} 60$-stimulated NOMO1 cells, compared with production in cells with negative-control siRNA knockdown (Fig. 4d). These results suggest that in human monocytes, TLR2 is involved in IL-8 secretion via activated ERK and p38 MAPK after rHpHSP60 stimulation.

\section{NF- $\kappa$ B activation and IL-8 mRNA expression via TLR2, ERK and p38 MAPK in NOMO1 cells reacted with rHpHSP60}

The transcription factor NF- $\kappa \mathrm{B}$ is a critical regulator of genes involved in inflammation, and it can be activated by intact $H$. pylori in monocytic/macrophage cells (Maeda et al., 2001). Our experiments showed that an increase in 


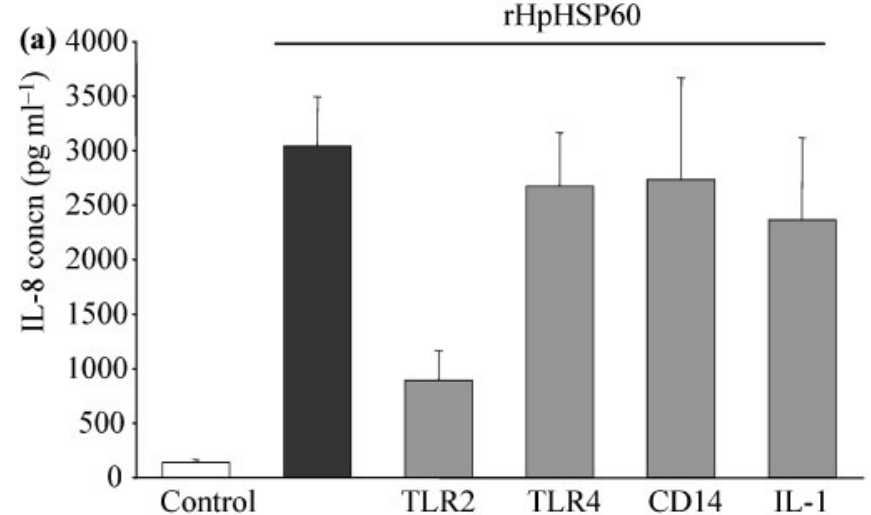

(b)

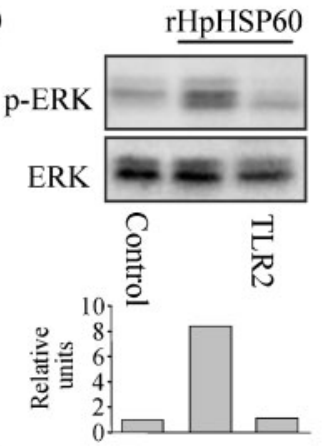

(c)
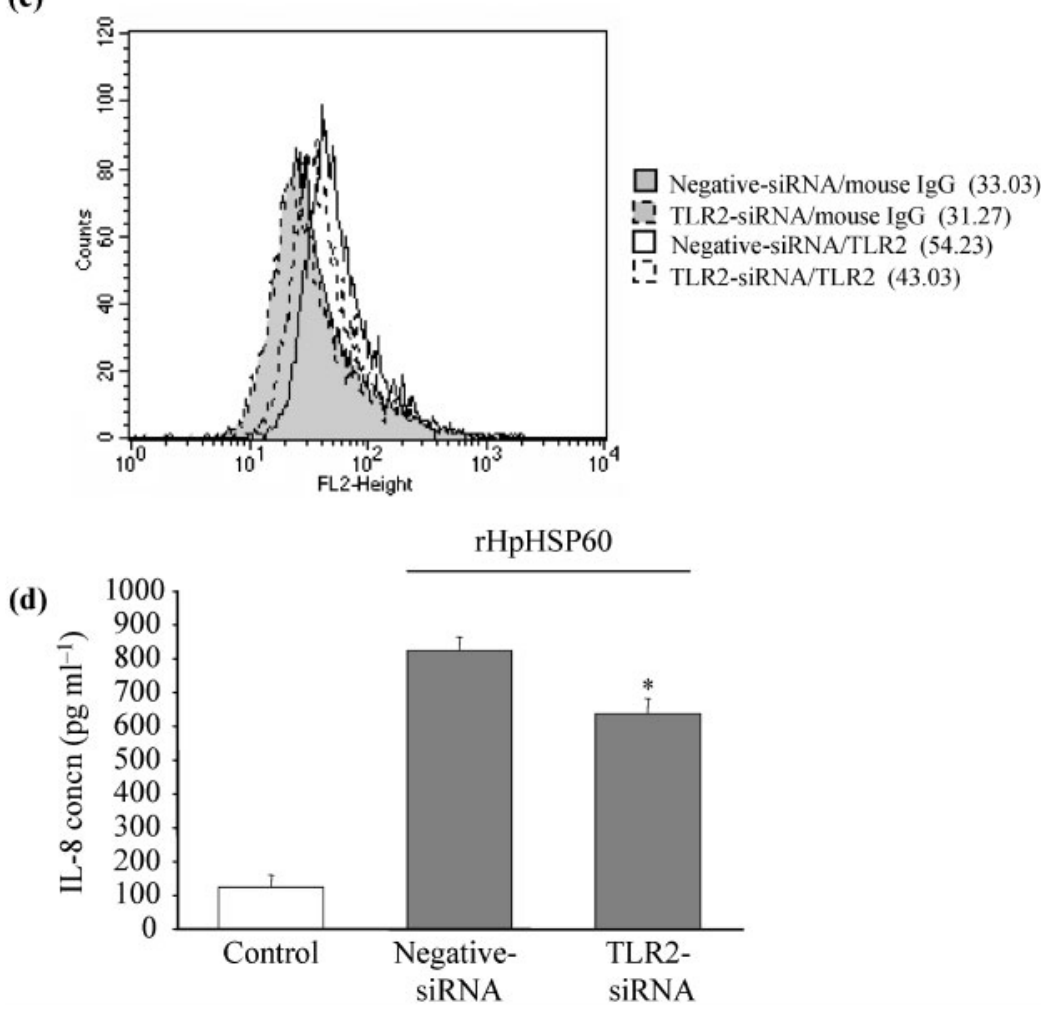

Fig. 4. Anti-TLR2 inhibits IL-8 secretion and ERK and p38 MAPK activation in rHpHSP60-treated monocytes, and IL-8 induction by TLR2 ligands is diminished in cells with siRNA targeted against TLR2. (a) NOMO1 cells $\left(2 \times 10^{6} \mathrm{ml}^{-1}\right)$ were pretreated for $30 \mathrm{~min}$ with anti-TLR2 $\left(10 \mu \mathrm{g} \mathrm{ml}^{-1}\right)$, antiTLR4 $\left(10 \mu \mathrm{g} \mathrm{ml}^{-1}\right)$, anti-CD14 (50 $\mathrm{g} \mathrm{ml}^{-1}$ ) and anti-IL-1 receptor $\left(10 \mu \mathrm{g} \mathrm{ml}^{-1}\right)$ before incubation with $\mathrm{rHpHSP60}\left(100 \mu \mathrm{g} \mathrm{ml}^{-1}\right)$ for $3 \mathrm{~h}$. The cell supernatants were measured for IL-8 release. Data are expressed as mean $\pm \mathrm{SD}(n=3)$. ${ }^{\star} P<0.05$ compared with $\mathrm{rHpHSP60}$ stimulation without antibody. (b) NOMO1 cells $\left(2 \times 10^{6} \mathrm{ml}^{-1}\right)$ were pretreated for $30 \mathrm{~min}$ with anti-TLR2 $\left(10 \mu \mathrm{g} \mathrm{ml}^{-1}\right)$ before incubation with $\mathrm{rHpHSP60}$ $\left(100 \mu \mathrm{g} \mathrm{ml}^{-1}\right)$ for $3 \mathrm{~h}$. The cell lysates were analysed by Western blotting using antibodies to either phospho-ERK ( $p$-ERK) or phospho-p38 ( $p$-p38). Antibodies to unphosphorylated ERK or p38 served as protein loading controls. Image Gauge software was used to calculate relative units to indicate the fold difference between $\mathrm{rHpHSP60}$-stimulated and non-stimulated cells after normalizing against ERK or p38. (c) NOMO1 cells transfected with TLR2-siRNA or negative-siRNA for $72 \mathrm{~h}$ were examined for surface expression of TLR2 by flow cytometry. Geometric mean fluorescence intensity values are given in the key at the right of the figure. (d) At $72 \mathrm{~h}$ post-transfection, cells were stimulated for $3 \mathrm{~h}$ with rHpHSP60 $\left(50 \mu \mathrm{g} \mathrm{ml}^{-1}\right)$. The supernatants were measured for IL-8 release. Data are expressed as mean $\pm \mathrm{SD}(n=3) .{ }^{*} P<0.05$ compared with negative siRNA. intranuclear NF- $\kappa \mathrm{B}$ was found $10 \mathrm{~min}$ after $\mathrm{rHpHSP60}$ stimulation, reaching its maximum level at $1 \mathrm{~h}$ after treatment (Fig. 5a). This reaction was significantly inhibited by pretreatment with SB203580, U0126 and anti-TLR2 antibody (Fig. 5b). These results showed that NF- $\kappa$ B may play an important role in response to $\mathrm{rHpHSP60-induced}$ IL-8 secretion via ERK and p38 binding in the TLR2 pathway. We have previously reported that $\mathrm{rHpHSP} 60$ induced IL-8 mRNA expression reaches its maximum at $1 \mathrm{~h}$ in U937 cells (Lin et al., 2005). In the present study, we 

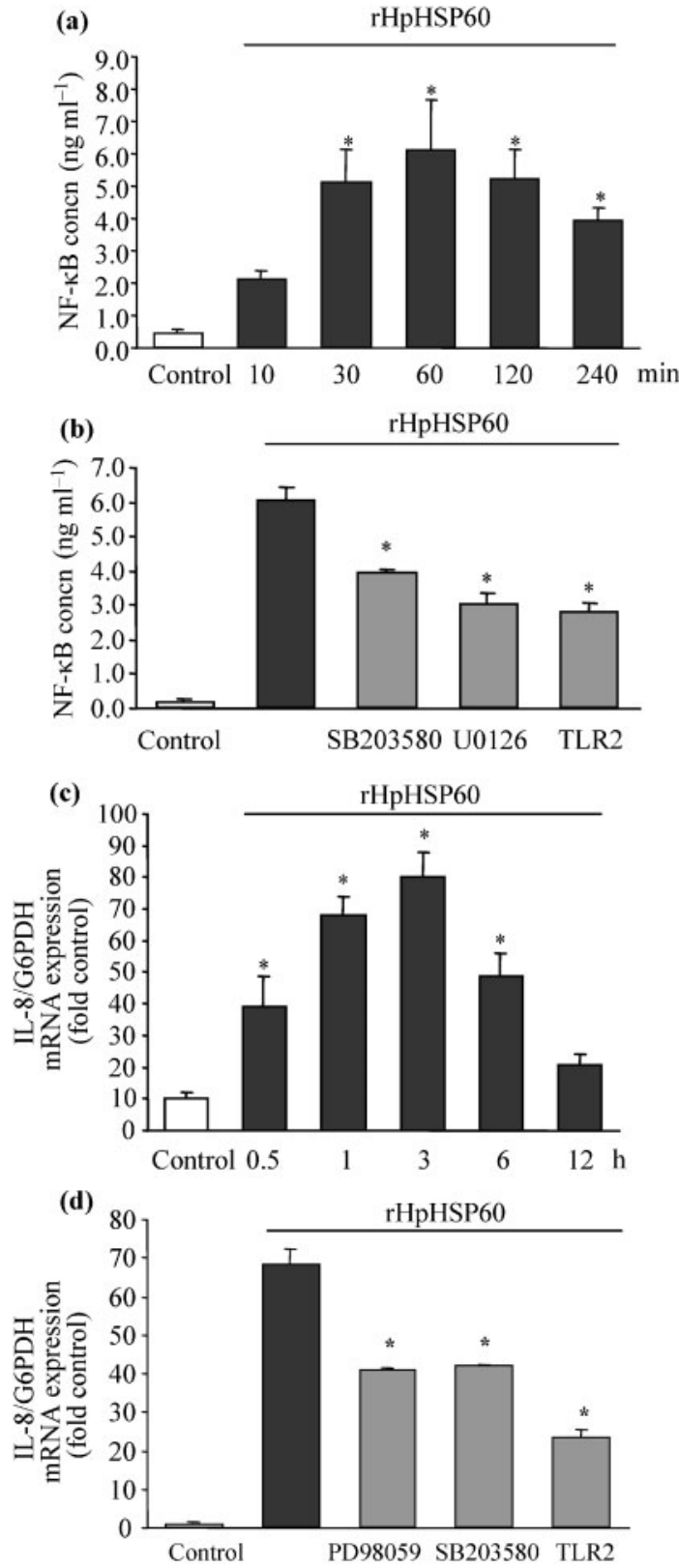

investigated IL-8 mRNA expression in NOMO1 cells by rHpHSP60 stimulation. The reaction reached its peak at $3 \mathrm{~h}$ (Fig. 5c), and was partially inhibited by the effect of PD98059, SB203580 and anti-TLR2 antibody (Fig. 5d).

\section{DISCUSSION}

HSPs, also called stress proteins, are a group of proteins present in both prokaryotic and eukaryotic cells. They are induced when a cell undergoes various types of environmental stress. HSPs trigger the immune response through activities that occur both inside (intracellular) and outside the cell (extracellular). Extracellular HSPs are the most powerful ways of sending a 'danger signal' to the immune system in order to generate a response that can help the
Fig. 5. U0126, PD98059, SB203580 and anti-TLR2 inhibit NF- $\kappa$ B activation and IL-8 mRNA expression in rHpHSP60-treated monocytes. (a) NOMO1 cells $\left(3 \times 10^{6} \mathrm{ml}^{-1}\right)$ were co-cultured with rHpHSP6O $\left(100 \mu \mathrm{g} \mathrm{ml}^{-1}\right)$ for the indicated periods. (b) NOMO1 cells $\left(3 \times 10^{6} \mathrm{ml}^{-1}\right)$ were pretreated for $30 \mathrm{~min}$ with U0126 $(10 \mu \mathrm{M}), \quad \mathrm{SB} 203580(5 \mu \mathrm{M})$ and anti-TLR2 $\left(10 \mu \mathrm{g} \mathrm{ml}^{-1}\right)$ before incubation with $\mathrm{rHpHSP60}\left(100 \mu \mathrm{g} \mathrm{ml}^{-1}\right)$ for $1 \mathrm{~h}$. The cell nuclear extracts were measured for NF- $\kappa \mathrm{B}$ activation. Data are expressed as mean $\pm \mathrm{SD}(n=3) .{ }^{*} P<0.05$ compared with control (a) and $\mathrm{rHpHSP} 60$ stimulation alone (b). (c) NOMO1 cells $\left(3 \times 10^{6} \mathrm{ml}^{-1}\right)$ were co-cultured with rHpHSP60 $\left(100 \mu \mathrm{g} \mathrm{ml}^{-1}\right)$ for the indicated periods. (d) NOMO1 cells $\left(3 \times 10^{6} \mathrm{ml}^{-1}\right)$ were pretreated for $30 \mathrm{~min}$ with PD98059 $(30 \mu \mathrm{M}), \quad$ SB203580 $(5 \mu \mathrm{M})$ and anti-TLR2 $\left(10 \mu \mathrm{g} \mathrm{ml}^{-1}\right)$ before incubation with $\mathrm{rHpHSP} 60\left(100 \mu \mathrm{g} \mathrm{m}^{-1}\right)$ for $3 \mathrm{~h}$. Samples were taken for RNA preparation, and real-time RT-PCR analyses were performed. Data are expressed as mean \pm SD $(n=3) .{ }^{*} P<0.05$ compared with control (c) and rHpHSP60 stimulation alone (d).

organism manage an infection or disease. HSPs have also been reported that are closely associated with the innate or adaptive immune systems (Ellis, 1990; Young, 1990). Bacterial HSPs have also been reported to have the capability to activate human monocytes and macrophages. HSPs from E. coli (GroES and DnaK) induce tumour necrosis factor alpha (TNF- $\alpha$ ), IL-6 and granulocyte-monocyte colonystimulating factor in monocytes (Galdiero et al., 1997). Chlamydial HSP60 enhances adhesion molecules on endothelial cells and induces proinflammatory cytokine IL-6 from macrophages (Bulut et al., 2002; Kol et al., 1998, 1999). Release of TNF- $\alpha$ and IL- $1 \beta$ by human mononuclear phagocytes in response to mycobacterial HSP65 indicates that the protein contributes to both host defence and tissue damage. HSP65 may play a role in the initiation of inflammation that adds to a non-species-specific resistance in the early stages of infection (Peetermans et al., 1994, 1995). Mycobacterial HSP65 may also be important in the host immune response and in the development of antigenspecific T-cell-mediated immunity (Friedland et al., 1993). Legionella HSP60 also possesses these activities (Retzlaff et al., 1994). These reports indicate that contact between bacterial HSP and human monocytes/macrophages is closely associated with innate or adaptive immune responses to bacterial infection. In this study, we have furthermore suggested that $H$. pylori-HSP60 mediates IL-8 production from human monocytes. The current results indicate that HSP60 may be an important molecule for the IL-8-inducing system in $H$. pylori infection.

The MAPK pathway is an important signal-transduction cascade and may involve the development of inflammation and/or cancer in $H$. pylori-infected mucosa. The MAPK pathway is activated by interaction between $H$. pylori and gastric epithelial cells via a type IV secretion system with the cag pathogenicity island (cagPAI) (Juttner et al., 2003; Shibata et al., 2005). Bhattacharyya et al. (2002) have reported that ERK, p38 and JNK regulate $H$. pylori-mediated 
IL-8 release from macrophages. Recently, the same group has found that IL- $1 \beta$ release induced by $H$. pylori LPS is associated with the PI-3/Akt/p38 MAPK pathway in macrophages (Basak et al., 2005). In this study, we demonstrated activation of ERK and p38 MAPK by rHpHSP60 as well as by intact $H$. pylori and heat-killed $H$. pylori stimulation; we think that $H$. pylori-HSP60 may play an important role in the activation of ERK and p38 MAPK, because HSP60 may be expressed on the bacterial surface. However, we did not identify activation of JNK by rHpHSP60. In addition, we found that IL-8 production was partially inhibited by ERK- and p38 MAPK-specific inhibitors. MAPK is a complex system involving many pathways; therefore, other pathways may be associated with activation of NF- $\kappa$ B (Fig. 6). Additional studies examining this possibility are needed.

In the innate immune response, HSPs engage signalling receptors that trigger NF- $\kappa \mathrm{B}$ activation and cytokine or chemokine release by monocytes/macrophages (Binder et al., 2004). Exogenous HSP70 stimulates cytokine production through a CD14-dependent pathway in HEK293 cells (Asea et al., 2002). CD14 is also a receptor for the LPS and LPS-binding protein (LBP) complex of H. pylori (Cunningham et al., 2000). The IL-1 receptor induces an increase in the expression of many genes with roles in immunity and inflammation by activating NF- $\kappa \mathrm{B}$ and p38 MAPK (O'Neill, 2000). HSP70, as an endogenous stimulus for the Toll/IL-1 receptor signal pathway, engages TLR2 and TLR4 (Vabulas et al., 2002). H. pylori activates NF- $\kappa$ B through CD14 and IL-1 receptor-associated kinase (IRAK) in monocytes (Maeda et al., 2001). We have previously reported TLR2 involvement in $H$. pylori-HSP60mediated IL-8 secretion in human gastric epithelial cells (Takenaka et al., 2004). In the current study, both anti-TLR2 antibody and siRNA were found to have potentially broad applications in the study of pathogens and TLR2 (Wang et al., 2005; Chen et al., 2006). To determine whether IL-8 secretion decreased in the absence of TLR2, we used siRNA to inhibit TLR2 and found that HSP60-mediated IL-8 secretion was partially suppressed. Anti-TLR4, -CD14 and -IL-1 receptor antibodies did not inhibit the IL-8 secretion in this study, indicating that TLR4, CD14 and IL-1 receptors may not be involved in IL-8 secretion by $\mathrm{rHpHSP} 60$ stimulation. It was also shown that there was no contamination in rHpHSP60 preparations. These results demonstrated that not only TLR 2 but also another receptor, although not TLR4, CD14 or the IL-1 receptor, may be involved in IL-8 secretion induced by $H$. pylori-HSP60 (Fig. 6).

The relationship between TLRs and $H$. pylori infection has been reported in many papers. H. pylori induces NF- $\kappa \mathrm{B}$ activation in epithelial cells primarily via TLR2 and TLR5 (Smith et al., 2003). TLR5 or TLR2 can mediate H. pyloriinduced IL-8 secretion via p38 MAPK signalling (Torok et al., 2005). H. pylori LPS stimulates TLR4 on gastric epithelial cells and activates NF- $\kappa \mathrm{B}$ and MOX1 (mitogen oxidase 1), which are associated with gastritis (Kawahara et al., 2001). Ishihara et al. (2004) have also demonstrated that LPS upregulates the host innate immunity through activation of the TLR-MD2 system in the stomach. We have also reported that $H$. pylori-HSP60 is recognized by TLR 2 on gastric epithelial cells and is associated with gastritis (Takenaka et al., 2004). TLR5 can recognize bacterial flagellin to mediate IL-8 secretion, but $H$. pylori flagellin evades TLR5-mediated innate immunity (Gewirtz et al., 2004). Recently, Cabral et al. (2006) have reported that the stimulation of TLR2 causes down-regulation of TLR5. Stimulation of TLR4 by LPS might enhance expression of TLR2 (Dr Keniti Amano, Akita University, personal communication). All this implies that the interaction mechanisms of TLR expression may be more complicated than we can imagine. Which TLRs play the main role in gastric mucosa infected by $H$. pylori is still obscure. This study indicates that TLR2 and $H$ pylori-HSP60 may be

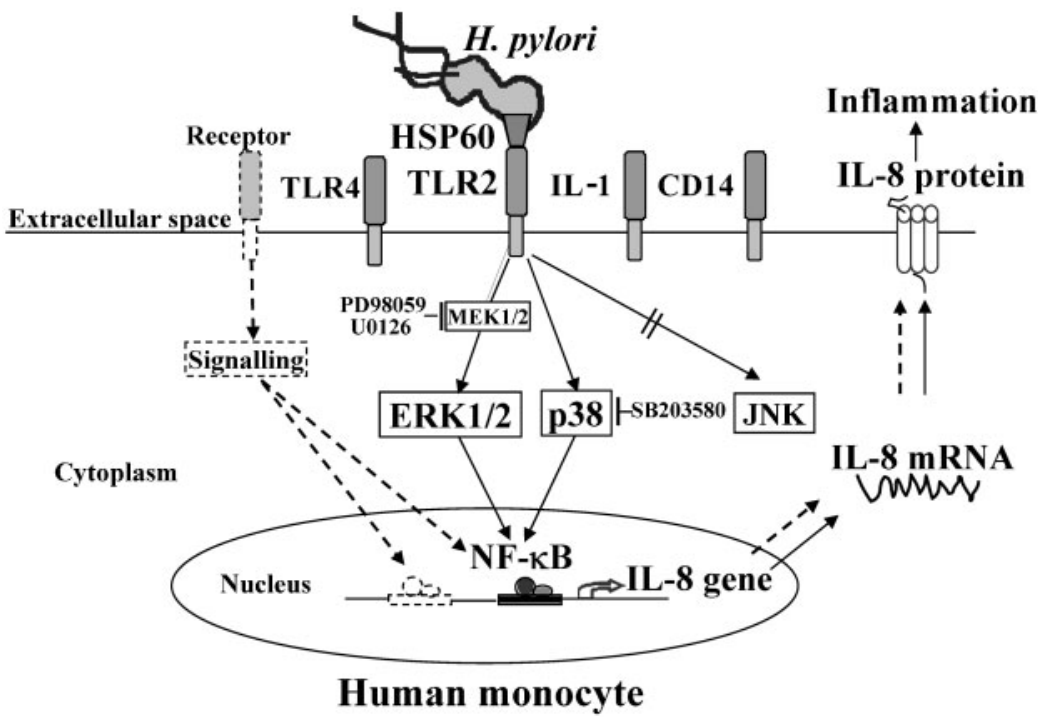

Fig. 6. Model of H. pylori-HSP60-mediated IL8 secretion downstream in human monocytes. 
primarily associated with the induction of IL-8 secretion in human monocytes.

Both LPS and HSP60 exist on the surface of $H$. pylori, and these antigens may stimulate the immune cells. The immune activity of LPS differs among various bacteria, and $H$. pylori LPS is 1000 times less effective than that of $E$. coli in inducing cytokine production in monocytes (Bliss et al., 1998). $H$. pylori LPS binds to LBP, and thus CD14-dependent cell activity is lower (Cunningham et al., 1996). The immune activity of HSP60 also differs among various bacteria. HSP60s have been compared for their ability to stimulate human peripheral blood mononuclear cell (PBMC) cytokine synthesis and vascular endothelial cell adhesion protein expression. In spite of their significant sequence homology, H. pylori-HSP60 is a more potent PBMC activator than Chlamydophila pneumoniae and human HSP60 (Maguire et al., 2005). It is possible that LPS and HSP60 are associated with the immune response in $\mathrm{H}$. pylori infection, but we still do not know whether one plays a major role or both are associated.

In this study, we focused on the downstream pathway of $H$. pylori-HSP60-induced IL-8 secretion in human monocytic cell lines. We have demonstrated that $H$. pylori-HSP60 induces the secretion of the inflammatory cytokine IL- 8 via the ERK and p 38 MAPK signalling pathways. In addition, we have found that TLR2, a recognition receptor for $H$. pyloriHSP60, likely plays an important role by initiating the ERK and p38 MAPK cascades in response to IL-8 secretion. TLR2, ERK and the p38 MAPK signal-transduction pathways lead to the activation of NF- $\kappa \mathrm{B}$ and expression of IL-8 mRNA. These findings support the idea that $H$. pyloriHSP60 plays an important role in stimulating production of pro-inflammatory cytokines, such as IL-8, in the innate immune response.

\section{REFERENCES}

Aihara, M., Tsuchimoto, D., Takizawa, H., Azuma, A., Wakebe, H., Ohmoto, Y., Imagawa, K., Kikuchi, M., Mukaida, N. \& Matsushima, K. (1997). Mechanisms involved in Helicobacter pylori-induced interleukin-8 production by a gastric cancer cell line, MKN45. Infect Immun 65, 3218-3224.

Asea, A., Rehli, M., Kabingu, E., Boch, J. A., Bare, O., Auron, P. E., Stevenson, M. A. \& Calderwood, S. K. (2002). Novel signal transduction pathway utilized by extracellular HSP70: role of Tolllike receptor (TLR) 2 and TLR4. J Biol Chem 277, 15028-15034.

Basak, C., Pathak, S. K., Bhattacharyya, A., Mandal, D., Pathak, S. \& Kundu, M. (2005). NF-kappaB- and C/EBPbeta-driven interleukin1beta gene expression and PAK1-mediated caspase-1 activation play essential roles in interleukin-1beta release from Helicobacter pylori lipopolysaccharide-stimulated macrophages. J Biol Chem 280, 4279-4288.

Bhattacharyya, A., Pathak, S., Datta, S., Chattopadhyay, S., Basu, J. \& Kundu, M. (2002). Mitogen-activated protein kinases and nuclear factor-kappaB regulate Helicobacter pylori-mediated interleukin-8 release from macrophages. Biochem J 368, 121-129.
Binder, R. J., Vatner, R. \& Srivastava, P. (2004). The heat-shock protein receptors: some answers and more questions. Tissue Antigens 64, 442-451.

Bliss, C. M., Jr, Golenbock, D. T., Keates, S., Linevsky, J. K. \& Kelly, C. P. (1998). Helicobacter pylori lipopolysaccharide binds to CD14 and stimulates release of interleukin-8, epithelial neutrophil-activating peptide 78 , and monocyte chemotactic protein 1 by human monocytes. Infect Immun 66, 5357-5363.

Brisslert, M., Enarsson, K., Lundin, S., Karlsson, A., Kusters, J. G., Svennerholm, A. M., Backert, S. \& Quiding-Jarbrink, M. (2005). Helicobacter pylori induce neutrophil transendothelial migration: role of the bacterial HP-NAP. FEMS Microbiol Lett 249, 95-103.

Bulut, Y., Faure, E., Thomas, L., Karahashi, H., Michelsen, K. S., Equils, O., Morrison, S. G., Morrison, R. P. \& Arditi, M. (2002). Chlamydial heat shock protein 60 activates macrophages and endothelial cells through Toll-like receptor 4 and MD2 in a MyD88-dependent pathway. J Immunol 168, 1435-1440.

Cabral, E. S., Gelderblom, H., Hornung, R. L., Munson, P. J., Martin, R. \& Marques, A. R. (2006). Borrelia burgdorferi lipoprotein-mediated TLR2 stimulation causes the down-regulation of TLR5 in human monocytes. J Infect Dis 193, 849-859.

Chen, K., Iribarren, P., Hu, J., Chen, J., Gong, W., Cho, E. H., Lockett, S., Dunlop, N. M. \& Wang, J. M. (2006). Activation of Toll-like receptor 2 on microglia promotes cell uptake of Alzheimer disease-associated amyloid beta peptide. J Biol Chem 281, 3651-3659.

Crabtree, J. E., Covacci, A., Farmery, S. M., Xiang, Z., Tompkins, D. S., Perry, S., Lindley, I. J. \& Rappuoli, R. (1995). Helicobacter pylori induced interleukin-8 expression in gastric epithelial cells is associated with CagA positive phenotype. J Clin Pathol 48, 41-45.

Cunningham, M. D., Seachord, C., Ratcliffe, K., Bainbridge, B., Aruffo, A. \& Darveau, R. P. (1996). Helicobacter pylori and Porphyromonas gingivalis lipopolysaccharides are poorly transferred to recombinant soluble CD14. Infect Immun 64, 3601-3608.

Cunningham, M. D., Shapiro, R. A., Seachord, C., Ratcliffe, K., Cassiano, L. \& Darveau, R. P. (2000). CD14 employs hydrophilic regions to 'capture' lipopolysaccharides. J Immunol 164, 3255-3263.

Ellis, R. J. (1990). The molecular chaperone concept. Semin Cell Biol 1, 1-9.

Evans, D. J., Jr, Evans, D. G., Takemura, T., Nakano, H., Lampert, H. C., Graham, D. Y., Granger, D. N. \& Kvietys, P. R. (1995). Characterization of a Helicobacter pylori neutrophil-activating protein. Infect Immun 63, 2213-2220.

Friedland, J. S., Shattock, R., Remick, D. G. \& Griffin, G. E. (1993). Mycobacterial $65-\mathrm{kD}$ heat shock protein induces release of proinflammatory cytokines from human monocytes. Clin Exp Immunol 91, 58-62.

Galdiero, M., de I'Ero, G. C. \& Marcatili, A. (1997). Cytokine and adhesion molecule expression in human monocytes and endothelial cells stimulated with bacterial heat shock proteins. Infect Immun $\mathbf{6 5}$, 699-707.

Gewirtz, A. T., Yu, Y., Krishna, U. S., Israel, D. A., Lyons, S. L. \& Peek, R. M., Jr (2004). Helicobacter pylori flagellin evades Toll-like receptor 5-mediated innate immunity. J Infect Dis 189, 1914-1920.

Gobert, A. P., Bambou, J. C., Werts, C., Balloy, V., Chignard, M., Moran, A. P. \& Ferrero, R. L. (2004). Helicobacter pylori heat shock protein 60 mediates interleukin-6 production by macrophages via a Toll-like receptor (TLR)-2-, TLR-4-, and myeloid differentiation factor 88-independent mechanism. J Biol Chem 279, 245-250.

Harris, P. R., Smythies, L. E., Smith, P. D. \& Dubois, A. (2000). Inflammatory cytokine mRNA expression during early and persistent Helicobacter pylori infection in nonhuman primates. J Infect Dis 181, 783-786. 
Ishihara, S., Rumi, M. A., Kadowaki, Y., Ortega-Cava, C. F., Yuki, T., Yoshino, N., Miyaoka, Y., Kazumori, H., Ishimura, N. \& other authors (2004). Essential role of MD-2 in TLR4-dependent signaling during Helicobacter pylori-associated gastritis. J Immunol 173, 1406-1416.

Ishii, E., Yokota, K., Sugiyama, T., Fujinaga, Y., Ayada, K., Hokari, I., Hayashi, S., Hirai, Y., Asaka, M., Oguma, K. \& other authors (2001). Immunoglobulin G1 antibody response to Helicobacter pylori heat shock protein 60 is closely associated with low-grade gastric mucosaassociated lymphoid tissue lymphoma. Clin Diagn Lab Immunol 8, 1056-1059.

Iwao, E., Hirayama, F., Takagi, S., Yokoyama, Y. \& Ikeda, Y. (1999). Virulence factors of Helicobacter pylori affecting its gastric colonization in Mongolian gerbils. J Gastroenterol 34 (Suppl. 11), 47-54.

Juttner, S., Cramer, T., Wessler, S., Walduck, A., Gao, F., Schmitz, F., Wunder, C., Weber, M., Fischer, S. M. \& other authors (2003). Helicobacter pylori stimulates host cyclooxygenase-2 gene transcription: critical importance of MEK/ERK-dependent activation of USF1/-2 and CREB transcription factors. Cell Microbiol 5, 821-834.

Kawahara, T., Kuwano, Y., Teshima-Kondo, S., Kawai, T., Nikawa, T., Kishi, K. \& Rokutan, K. (2001). Toll-like receptor 4 regulates gastric pit cell responses to Helicobacter pylori infection. J Med Invest 48, 190-197.

Keates, S., Keates, A. C., Warny, M., Peek, R. M., Jr, Murray, P. G. \& Kelly, C. P. (1999). Differential activation of mitogen-activated protein kinases in AGS gastric epithelial cells by cag + and cagHelicobacter pylori. J Immunol 163, 5552-5559.

Kol, A., Sukhova, G. K., Lichtman, A. H. \& Libby, P. (1998). Chlamydial heat shock protein 60 localizes in human atheroma and regulates macrophage tumor necrosis factor-alpha and matrix metalloproteinase expression. Circulation 98, 300-307.

Kol, A., Bourcier, T., Lichtman, A. H. \& Libby, P. (1999). Chlamydial and human heat shock protein 60 s activate human vascular endothelium, smooth muscle cells, and macrophages. J Clin Invest 103, 571-577.

Kyriakis, J. M. \& Avruch, J. (2001). Mammalian mitogen-activated protein kinase signal transduction pathways activated by stress and inflammation. Physiol Rev 81, 807-869.

Lin, S. N., Ayada, K., Zhao, Y., Yokota, K., Takenaka, R., Okada, H., Kan, R., Hayashi, S., Mizuno, M. \& other authors (2005). Helicobacter pylori heat-shock protein 60 induces production of the pro-inflammatory cytokine IL8 in monocytes. J Med Microbiol 54, 225-233.

Maeda, S., Akanuma, M., Mitsuno, Y., Hirata, Y., Ogura, K., Yoshida, H., Shiratori, Y. \& Omata, M. (2001). Distinct mechanism of Helicobacter pylori-mediated NF-kappa B activation between gastric cancer cells and monocytes. J Biol Chem 276, 44856-44864.

Maguire, M., Poole, S., Coates, A. R., Tormay, P., Wheeler-Jones, C. \& Henderson, B. (2005). Comparative cell signalling activity of ultrapure recombinant chaperonin 60 proteins from prokaryotes and eukaryotes. Immunology 115, 231-238.

Mann, N. S. \& Westblom, T. U. (1999). Helicobacter pylori and the future: an afterword. Curr Top Microbiol Immunol 241, 301-308.

O'Neill, L. (2000). The Toll/interleukin-1 receptor domain: a molecular switch for inflammation and host defence. Biochem Soc Trans 28, 557-563.
Peetermans, W. E., Raats, C. J., Langermans, J. A. \& van Furth, R. (1994). Mycobacterial heat-shock protein 65 induces proinflammatory cytokines but does not activate human mononuclear phagocytes. Scand J Immunol 39, 613-617.

Peetermans, W. E., Raats, C. J., van Furth, R. \& Langermans, J. A. (1995). Mycobacterial 65-kilodalton heat shock protein induces tumor necrosis factor alpha and interleukin 6, reactive nitrogen intermediates, and toxoplasmastatic activity in murine peritoneal macrophages. Infect Immun 63, 3454-3458.

Retzlaff, C., Yamamoto, Y., Hoffman, P. S., Friedman, H. \& Klein, T. W. (1994). Bacterial heat shock proteins directly induce cytokine mRNA and interleukin-1 secretion in macrophage cultures. Infect Immun 62, 5689-5693.

Sarsfield, P., Jones, D. B., Wotherspoon, A. C., Harvard, T. \& Wright, D. H. (1996). A study of accessory cells in the acquired lymphoid tissue of helicobacter gastritis. J Pathol 180, 18-25.

Shibata, W., Hirata, Y., Yoshida, H., Otsuka, M., Hoshida, Y., Ogura, K., Maeda, S., Ohmae, T., Yanai, A. \& other authors (2005). NFkappaB and ERK-signaling pathways contribute to the gene expression induced by cag PAI-positive-Helicobacter pylori infection. World J Gastroenterol 11, 6134-6143.

Smith, M. F., Jr, Mitchell, A., Li, G., Ding, S., Fitzmaurice, A. M., Ryan, K. Crowe, S. \& Goldberg, J. B. (2003). Toll-like receptor (TLR) 2 and TLR5, but not TLR4, are required for Helicobacter pylori-induced NFkappa B activation and chemokine expression by epithelial cells. J Biol Chem 278, 32552-32560.

Suzuki, T., Kato, K., Ohara, S., Noguchi, K., Sekine, H., Nagura, H. \& Shimosegawa, T. (2002). Localization of antigen-presenting cells in Helicobacter pylori-infected gastric mucosa. Pathol Int 52, 265-271.

Takenaka, R., Yokota, K., Ayada, K., Mizuno, M., Zhao, Y., Fujinami, Y., Lin, S.-N., Toyokawa, T., Okada, H. \& other authors (2004). Helicobacter pylori heat-shock protein 60 induces inflammatory responses through the Toll-like receptor-triggered pathway in cultured human gastric epithelial cells. Microbiology 150, 3913-3922.

Torok, A. M., Bouton, A. H. \& Goldberg, J. B. (2005). Helicobacter pylori induces interleukin-8 secretion by Toll-like receptor 2- and Toll-like receptor 5-dependent and -independent pathways. Infect Immun 73, 1523-1531.

Vabulas, R. M., Ahmad-Nejad, P., Ghose, S., Kirschning, C. J., Issels, R. D. \& Wagner, H. (2002). HSP70 as endogenous stimulus of the Toll/interleukin-1 receptor signal pathway. J Biol Chem 277, 15107-15112.

Wang, J. P., Kurt-Jones, E. A., Shin, O. S., Manchak, M. D., Levin, M. J. \& Finberg, R. W. (2005). Varicella-zoster virus activates inflammatory cytokines in human monocytes and macrophages via Toll-like receptor 2. J Virol 79, 12658-12666.

Yamaoka, Y., Kwon, D. H. \& Graham, D. Y. (2000). A $M_{\mathrm{r}} 34,000$ proinflammatory outer membrane protein (oipA) of Helicobacter pylori. Proc Natl Acad Sci U S A 97, 7533-7538.

Yokota, K., Kurebayashi, Y., Takayama, Y., Hayashi, S., Isogai, H., Isogai, E., Imai, K., Yabana, T., Yachi, A. \& Oguma, K. (1991). Colonization of Helicobacter pylori in the gastric mucosa of Mongolian gerbils. Microbiol Immunol 35, 475-480.

Young, D. B. (1990). Chaperonins and immune response. Semin Cell Biol 1, 27-35.

Zhang, D., Zhang, G., Hayden, M. S., Greenblatt, M. B., Bussey, C., Flavell, R. A. \& Ghosh, S. (2004). A Toll-like receptor that prevents infection by uropathogenic bacteria. Science 303, 1522-1526. 